\title{
THE INFLUENCE OF NIEUWE BOUWEN ARCHITECTURE ON DUTCH COLONIAL BUILDING IN MEDAN CITY
}

\author{
Imam Faisal Pane ${ }^{1}$, Ribka A. Sianipar ${ }^{2 *}$ \\ ${ }^{1,2}$ Department of Architecture, Faculty of Engineering, University of Sumatera Utara, Kampus USU Medan 20155 , \\ INDONESIA \\ *Corresponding author; Email: ripkasianipar94@gmail.com
}

\begin{abstract}
Nieuwe Bouwen Architecture came and involved in Indonesia is carried by the young Dutch architects, also influenced Dutch colonial building in Indonesia to include Medan city. This study aims to determine what kind of Nieuwe Bouwen that control Dutch colonial buildings in Medan and find the form of the authority. This study used the qualitative method. There are 6 (six) aspects studied in this research that is the dynamic form; expressive ornaments; the building has a tower; nonstructural elements; glass, steel, and concrete materials; elements of air, light, and space. Analysis results show that PD Pasar Office Medan, Paradiso Swimming Pool, and Mandiri KC Medan City Hall Bank are influenced by Nieuwe Bouwen expressionism. Besides that, the form of expressionism on PD Pasar office Medan are of the curved shape of the building, unique, the expressive ventilation has the ornament and decorative element on its facade. As well as Paradiso swimming pool has curved shape, decoration and decorative element on its façade and tower. While at Mandiri KC Medan Cityhall bank, there is the geometric decoration, decorative element, and balcony also tower have expressive shape.
\end{abstract}

Keywords: Nieuwe Bouwen; Dutch colonial building; expressionism.

\section{INTRODUCTION}

Modern architecture went international in the early of the $19^{\text {th }}$ century that was marked by happening the industrial revolution in the form of rationalization and the use of machinery on a large scale because of the construction method that uses is the fabrication (Sumalyo, 1997). Style of this architecture emphasizes the functionality and technology, not only as art. One of the modern architectural character or concepts propagated CIAM congress was the architecture of Nieuwe Bouwen. Nieuwe Bouwen architecture is modern Dutch architecture that means new building (new construction). The main slogans of this architecture are light, air, and space (Ibelings, 1995). This term began to evolve in Netherland after 1920 and then came into Indonesia that was brought by young Dutch architect and influenced Dutch colonial architecture in Indonesia (Handinoto, 1996). At that time the influence of modernization is becoming a trend, this influence is more or less influenced the development of architecture. European modernization movement brought to Indonesia by the Dutch, one of them in the form of architectural styles. Nieuwe Bouwen architecture was one of style of architecture that brings the change in the Dutch colonial architecture and the most accessible to be used by young Dutch architect at the time in Indonesia include Medan city.

In Indonesia, there are quite a lot of Dutch colonial building that was influenced by Nieuwe
Bouwen architecture, include in Medan. However, only three buildings that have not experienced a change in shape of the building, so that it can become the object of research, namely PD Pasar office, Paradiso swimming pool, and Mandiri KC Medan Cityhall bank. This study was conducted to determine what kind of Nieuwe Bouwen architecture that influences Dutch colonial building in Medan which can be seen from the three object of research and find the form of that control. The necessary data to see the style of building can see from the façade of the building.

\section{Nieuwe Bouwen Architecture}

Nieuwe Bouwen architecture is the modern architecture in Netherland that appeared at the end of $19^{\text {th }}$ century after World War I that was pioneered by H.P Berlage. Nieuwe Bouwen term appeared because there is a pretension to leave the past (old style in architecture) with the way was propagating new architecture to the citizen with new culture for people who have released after World War I. This term began to develop at the 1920s.

Nieuwe Bouwen architecture was the new architecture (new construction), namely: new material (concrete, glass, and steel), new structure, and new production method. Word "new" become the keyword for this movement. The concepts of Nieuwe Bouwen are flexible architecture, light, transparent, health, and hygiene (Muller, 2011). The most impor- 
tant and main slogans of this architecture are light, air, and space (Ibelings, 1995) because the essential in Nieuwe Bouwen architecture is openness (Muller, 2011). Besides transparency, this architecture also applies rationalization because development does with sophisticated techniques and prioritizing science, so the system is rational construction. This concept was propagated at CIAM congress (Rebel, 1983). Besides that, Nieuwe Bouwen architects thought necessary of the user of building to give the comfortable feeling, warm, and healthy life environment in building (Dietz. et al., 1995).

\section{The Types of Nieuwe Bouwen Architecture}

\section{Nieuwe Bouwen Expressionism Architecture}

Nieuwe Bouwen expressionism is a new architecture (new trend) that has expressionist style. One of the examples was Amsterdam school that evolved in Netherland at 1915 until the 1930s. This architecture is consist of the pattern the wide variety of brick that is compiled with high skill and the shape is such plasticity (easily formed). In other words, apply the brick expressionism in that buildings. Besides that, it has an expressive shape as a curved shape which building that has curved shape was the characteristic of expressionism architecture (Wertheimer, 2004; Bogdanovic. et al., 2014). There are some ornaments, although architect and expert crafts often worked together, they considered that architecture was the primary element, so it has to arrange all art (Handinoto, 2010).

Amsterdam school is also called as "Rationalist as Expressionist," and H.P Berlage had a significant role in this movement, so Amsterdam school still handle the rationalist basis for his work, although this trend emphasizes the expression for that shape (Handinoto, 2010). One of the examples of that building that applied Amsterdam School architecture, namely: Het Schip is built in 1917 in Amsterdam.There are two examples of the building was designed by using the Amsterdam School style, namely: De Bijenkorf and Het Schip (Figure 1).

Expressionist shape not only shaped distortion, but also some architects express expression geometric shape, namely Willem Marinus Dudok was a Nieuwe Bouwen architect (Harmans, 2011) that was influenced by expressionism architecture (Samuels, et al., 2004). He applied the concept of cubistic expressionism in his work (Kolman, et al., 1997) (Figure 2). The example of the building was influenced by Nieuwe Bouwen expressionist architecture that was applied that concept was Town Hall Hilversum. On this building, there is the expressive shape, geometric ornaments on his tower and decorative elements on the window (Figure 3).
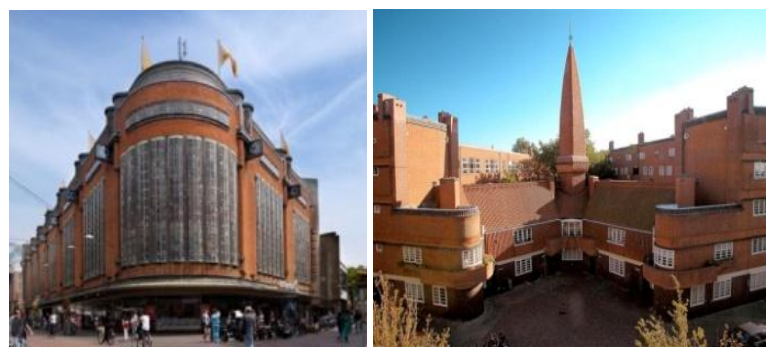

Fig. 1. De Bijenkorf and Het Schip (Source: Panoramio and Het Schip)
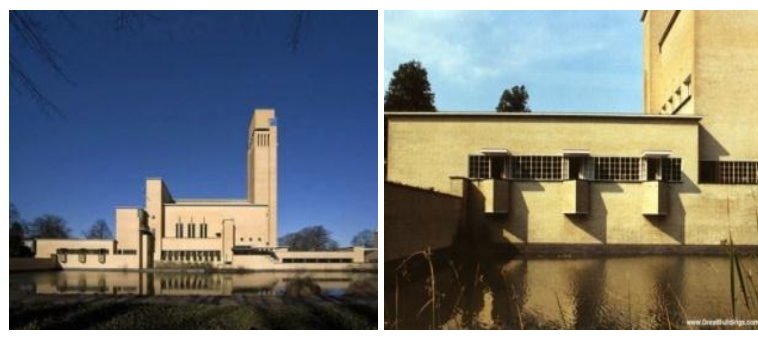

Fig. 2. Town Hall Hilversum and Expressive Balcony (Source: Commons.wikimedia and Great buildings)

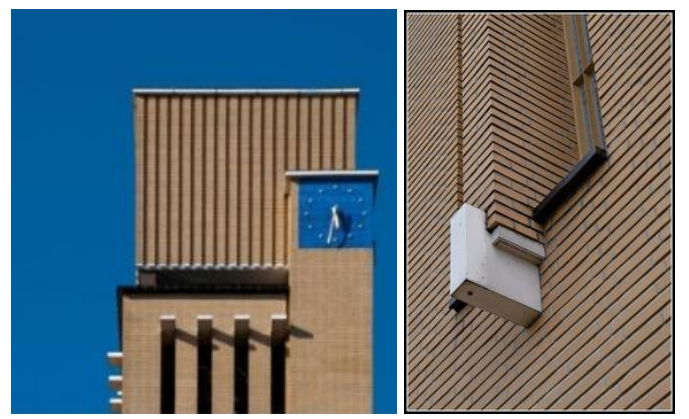

Fig. 3. Geometric Ornament on Tower and Decorative element on window (Source: Pinterest and Flickr)

\section{Nieuwe Bouwen Functionalism Architecture}

Nieuwe Bouwen Functionalism architecture was the new building/architecture that has functionalism style in Netherland. This architecture was so prioritizing the rationalization in building the simple form that consists the geometric shape which is the form geometry is generated by rational thinking (Wahid \& Alamsyah, 2013). Geometric shapes in functionalism architecture were cube and block which constitute a unified way. So that the trend was often called cubism architecture (Sumalyo, 1997). The example of the buildings that applied this architecture was a house that was designed by J.J.P Oud in Weissenhofsiedlung housing, the house of Van der Leeuw, and Sonneveld house (Figure 4). 

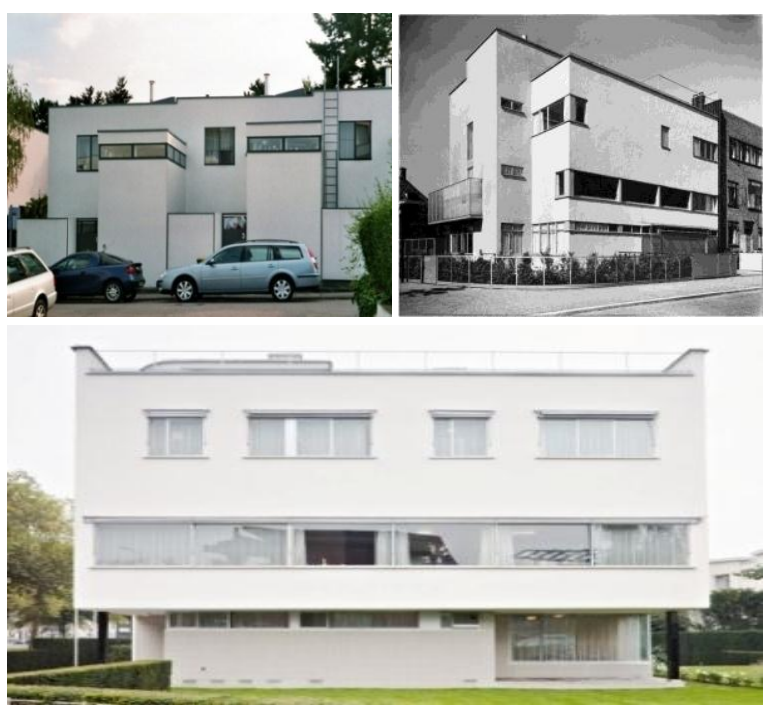

Fig. 4. House was Designed by J.J.P Oud, House of Van der Leeuw, and House of Sonneveld (Source: Wikipedia, Functionmag.tumblr, and Nai)

\section{Nieuwe Bouwen Local Architecture}

Nieuwe Bouwen Local was Nieuwe Bouwen architecture that got the influence of traditional architecture. In other words, happened the merger between modern architecture with traditional architecture on the building of Nieuwe Bouwen Local. Dutch traditional architecture was marked by the building in monumental scale. There were gevel, chimneys, the small windows, decorative ornaments or statues, and saddle roof (Ibelings, 1995). While the material of modern architecture were concrete, steel, and glass (Ibelings, 1995: Muller, 2011). The example of the buildings that were applied Nieuwe Bouwen Local architecture were Amsterdam Exchange, Amstel Brewery office, and Zuidplein flats (Figure 5).
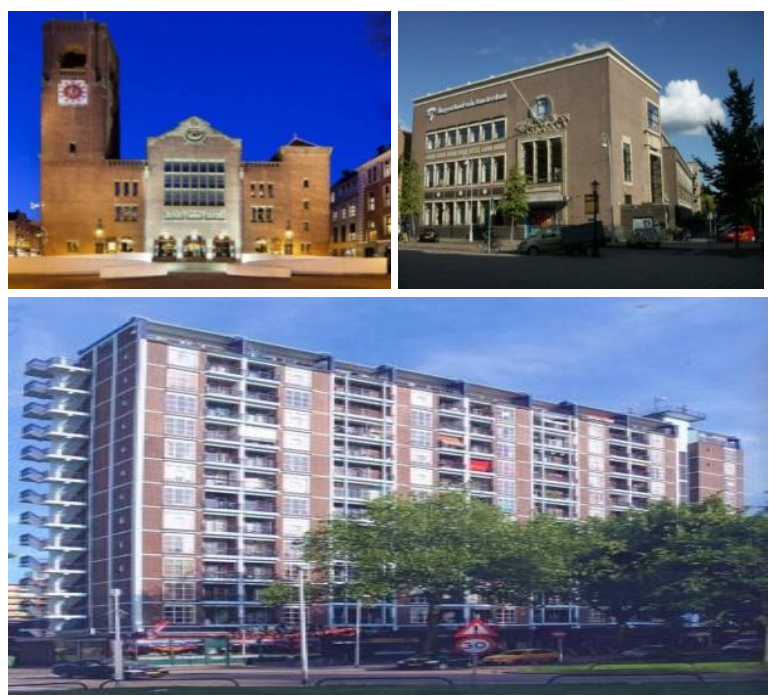

Fig. 5. Amsterdam Exchange, Amstel Brewery Office, and Zuidplein Flats (Source: Commons.Wikimedia, Panoramio, and Pinterest)

\section{METHODOLOGY}

The method used was the qualitative approach, namely collecting primary data by observing the object of the study and interview to know the history and condition of the object of research. The building that became the object of the study were PD Pasar Office, Paradiso Swimming Pool, and Mandiri KC Medan City Hall Bank (Figure 6). Besides collecting primary data, the researcher also collected secondary data with doing literature study. After collecting data, the researcher analyzed primary data with connecting to the theory that was used in this research to get the result of the study, so the researcher knew what kind of Nieuwe Bouwen that influence Dutch colonial buildings in Medan and find the form of the influence.

In analyzing data, the method used was the descriptive approach. Descriptive method is a data analysis technique by describing the object of research or explain what their situation. This method was used to determine what kind of Nieuwe Bouwen that influence that object of research. Observations in the field based on the results of the literature review that has been done. According to that, there are 6 aspects: the dynamic form; expressive ornaments; the building has a tower; nonstructural elements; glass, steel, and concrete materials; elements of air, light, and space. These aspects are analyzed to determine the type of Nieuwe Bouwen that develops in the field.

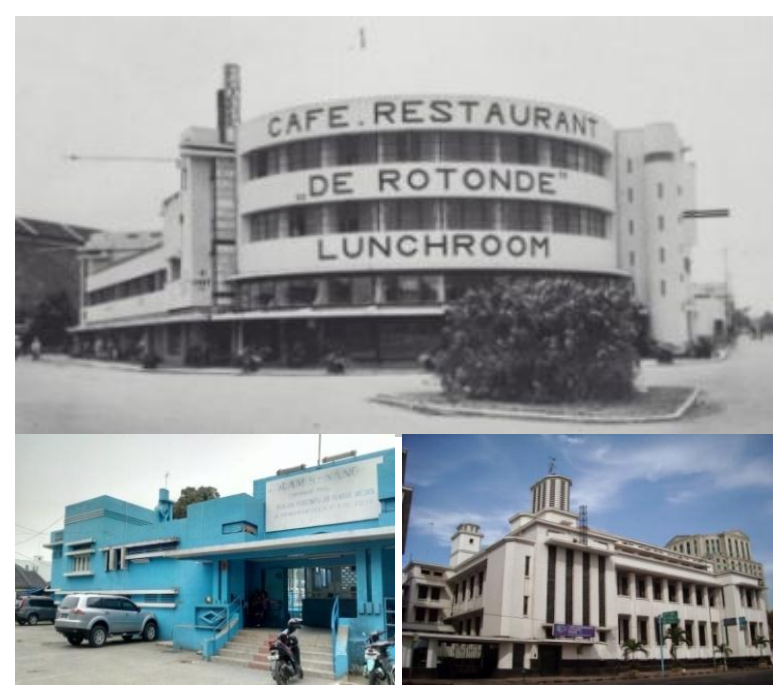

Fig. 6. PD Pasar Office Medan, Paradiso Swimming pool, and Mandiri KC Medan City Hall Bank (from left to right) (Source: Tropenmuseum, Personal, and Google)

\section{RESULT AND DISCUSSION}

\section{PD Pasar Office Medan}

PD Pasar building has a semicircular shape, and there is the curved shape on the left side of the building. It indicates that the influence of Expres- 
sionist flow in this building which is the curved buildings is the characteristic of expressionism architecture (Wertheimer, 2004; Bogdanovic et al., 2014). Besides that, there are ornament and ventilation in this building that has expressive form and not rigid (Figure 7).

There is a tower that was made of the brick material that wasn't plastered (brick expose) on this building. Although the shape of the tower was not expressive, its constituent materials was a hallmark of expressionism architecture. Besides that, some elements don't function as the structure on the facade of the building, but it's just decorative items (Figure 8).

In this building, materials used was the same as building in Nieuwe Bouwen architecture, namely: glass, steel, and concrete. The use of material that dominates on the facade is glass and glass frame was made of steel, while the structure of this building used reinforced concrete. Besides material, the opening on the facade is so many, so air and light can get into the room to illuminate the room in the building (Krier, 2001). It shows that the building so looks at the main slogan of this architecture, namely: air, light, and space (Figure 9).

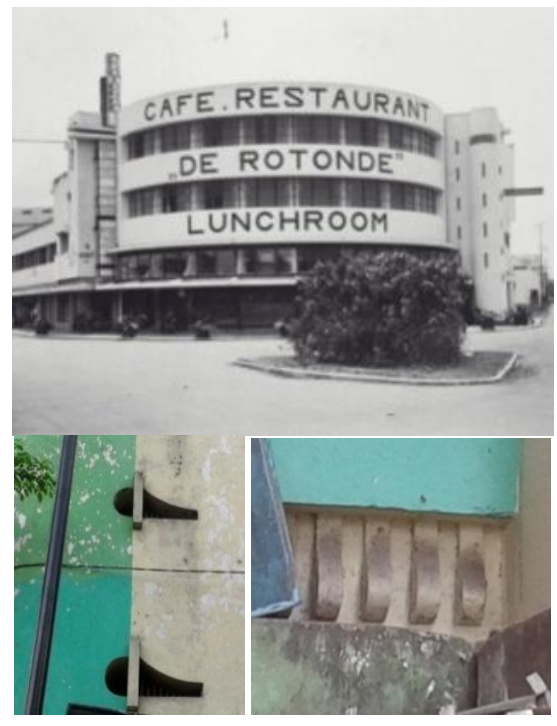

Fig. 7. The Form of the Building and the Expressive Ventilation on Facade and there was Ornament on Façade (Source: Tropenmuseum)

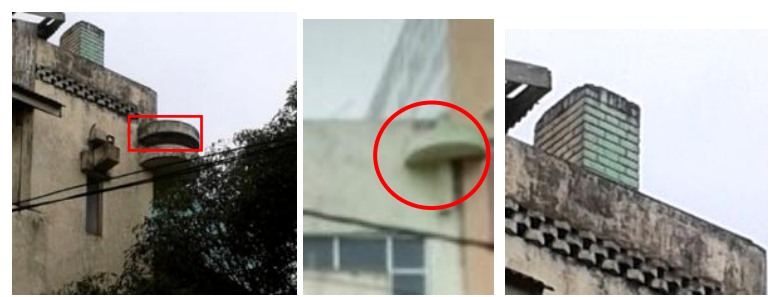

Fig. 8. There was Decorative element on facade and Expressive tower and ventilation
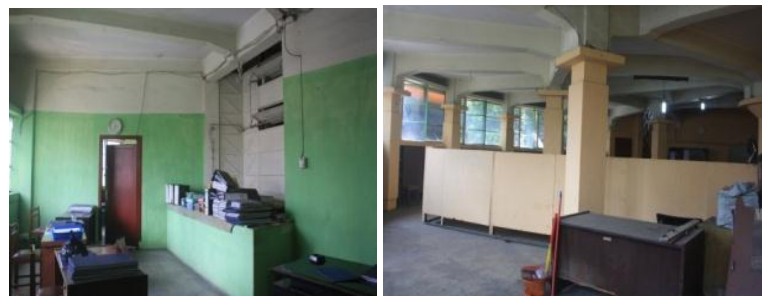

Fig. 9. Room Atmosphere that shows natural light into the PD Pasar office Medan

From the result of the analysis, the conclusion is PD Pasar office is a Dutch colonial building that was influenced by Nieuwe Bouwen Expressionism.

\section{Paradiso Swimming Pool}

The form of this swimming pool is consist of cube shape on the front facade and curved shape on the left side and rear facade. It means that there was the influence of Expressionist trend in this building which the curved shape is the characteristic of expressionism architecture (Wertheimer, 2004; Bogdanovic et al., 2014). On the front facade, there is dynamical geometric composition. There is a play of mass formation which shift forward or backward, and the roof is not uneven. One of the examples of Expressionism Nieuwe Bouwen applied this concept, namely Town Hall Hilversum by W.M Dudok. On this building also use dynamical geometric composition concept (Bergeijk \& Dudok, 2001) (Figure 10).

There are an expressive tower, the decorative element on right side facade, and geometric ornament on the front facade. Besides that, on the right side and rear facade was made of brick that is not plastered (brick expose). This swimming pool is an outdoor swimming pool, so air and light can fulfill the space in the building. Beside that, this building also used the concrete mushroom column as the structure element which one of the examples of Nieuwe Bouwen building, namely: Van Nelle factory also used this column (Figure 11, 12 and 13)

In this building, there is reinforced concrete, and guardrail was made of steel material, and on the wall, there is glass block which these third materials are the main materials on Nieuwe Bouwen architecture (Ibelings, 1995). Besides the use of modern material, there is a courtyard in this building. This courtyard becomes open space in this building and can be a green area which the green area is one of the important aspects of Nieuwe Bouwen architecture (Dietz, et al., 1995). Beside that, according to Segaar-Höweler (1998), this swimming pool was the example of Dutch colonial building that was influenced by Nieuwe Bouwen architecture (Figure 14). 

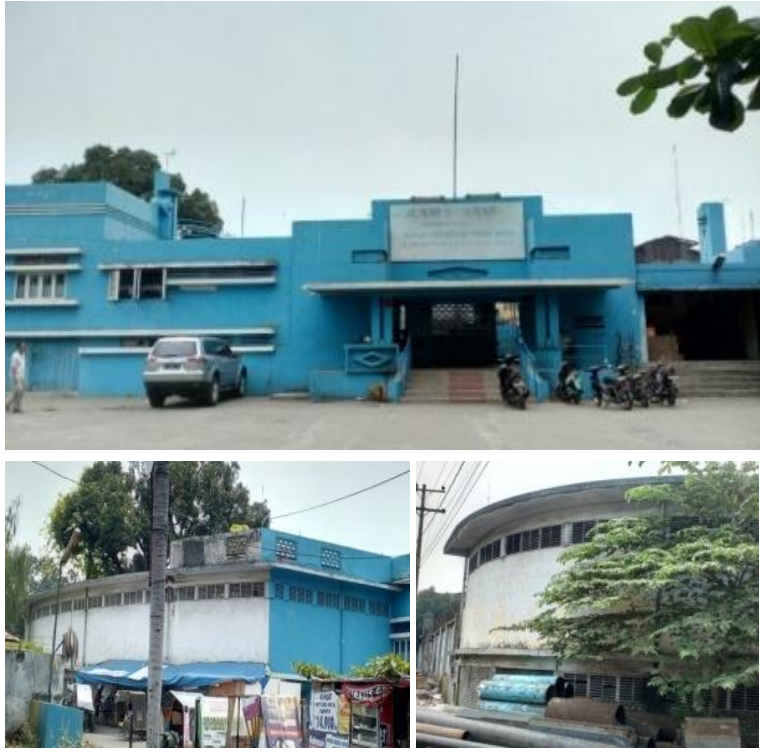

Fig. 10. The Front Facade and the Curvature on the sides and back of the Paradiso swimming pool

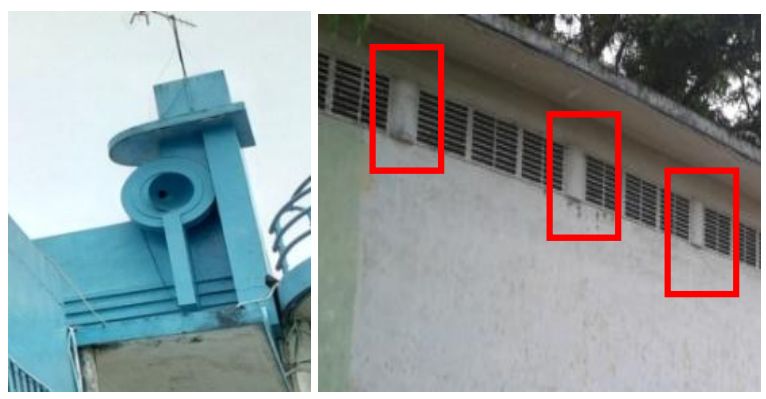

Fig. 11. Tower has the Expressive form and Decorative element on facade

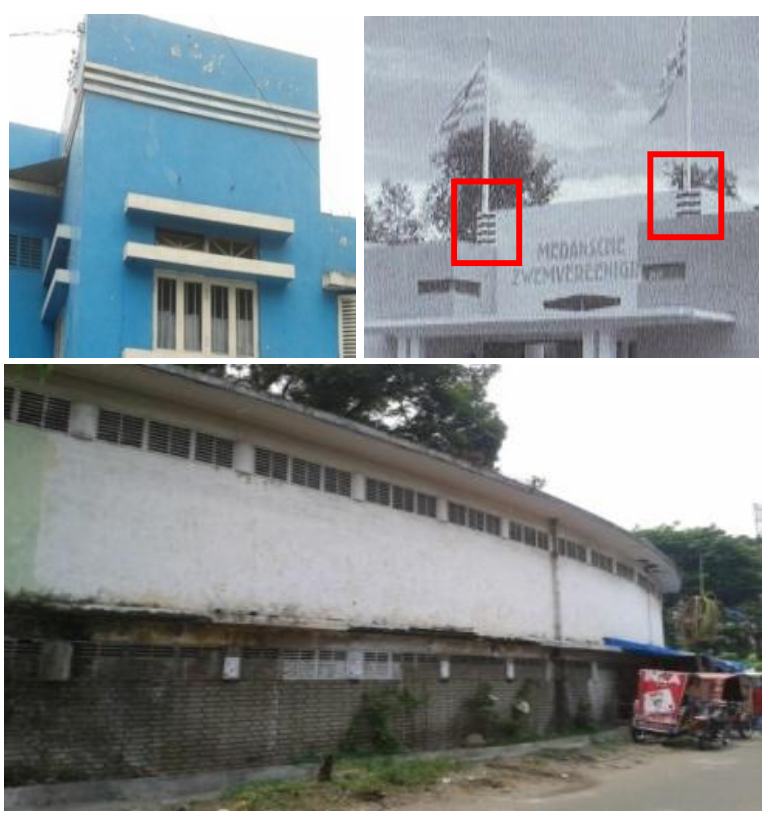

Fig. 12. Ornament on front Facade and Brick was not plastered on side wall (Source: Semedan)

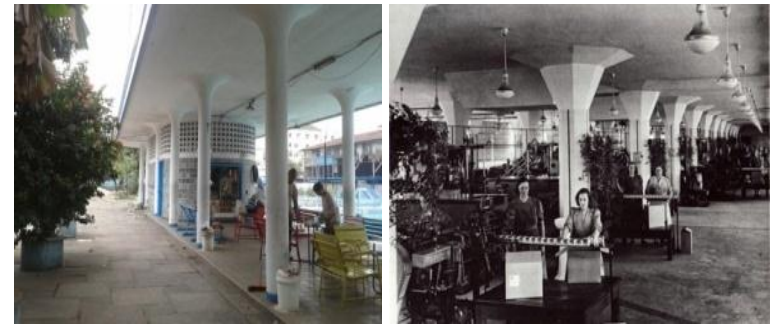

Fig. 13. Concrete Mushroom Column on Paradiso Swimming Pool and Van Nelle factory (Source: Personal and Facilitaire-info)
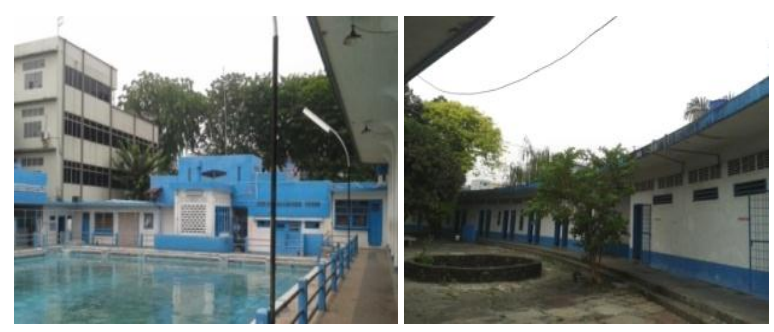

Fig. 14. Courtyard Atmosphere in the Building

From the result of the analysis, the conclusion is Paradiso swimming pool is a Dutch colonial architecture that was influenced by Nieuwe Bouwen Expressionism.

\section{Mandiri KC Medan City Hall Bank}

This building has the rigid form that consists of cubes and block. Vertical and horizontal elements are visible on the facade. One of the examples of expressionism Nieuwe Bouwen building also applied it, namely Townhall Hilversum. Besides that, this building has the balcony on the front and side of the building so that it can be a transitional space between outer space and inner space, as well as the outer wall and inner wall does not converge. It is the concept of cubism trend which Nieuwe Bouwen architecture applied this trend (Sumalyo, 1997). Besides the use of the balcony, the number of openings in the facade of the building, use of modern materials, such as glass, steel, and concrete is also a characteristic of the Nieuwe Bouwen architecture (Figure 15 and 16).

Besides the use of modern materials in this building, there are the corona decorative element on the $1^{\text {st }}$-floor walls, and under the balcony on $2^{\text {nd }}$ floor. It has the geometric ornament on the column, and has the expressive tower, as well as nearly every corner of the building, were curved, so it looks like curving which can be seen on the balcony, the building tower, and corner on the facade of the building. It means there is the influence of expressionism architecture on this building (Figure 17). 

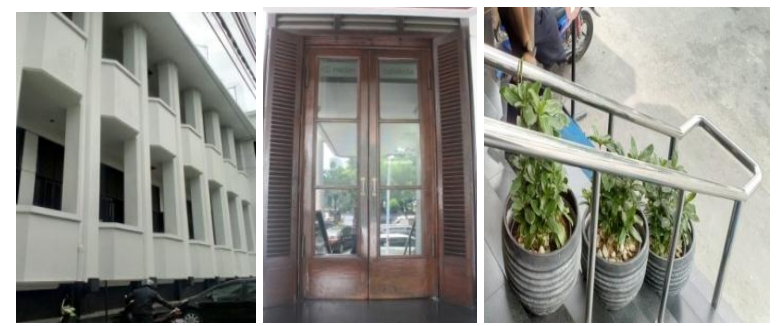

Fig. 15. Balcony on right side of building, glass material at door, and steel material in railing
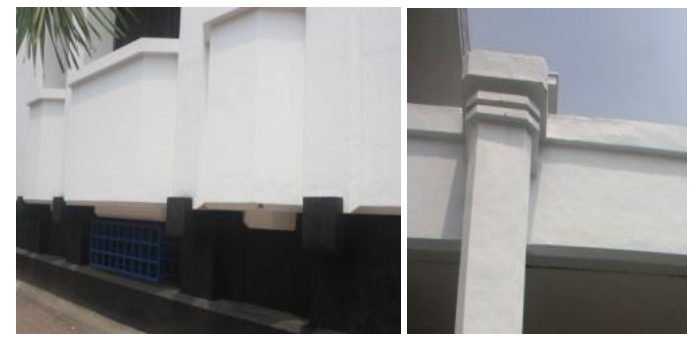

Fig. 16. Decorative elements on wall of $1^{\text {st }}$ floor and under the balcony, and geometric ornament on a building column
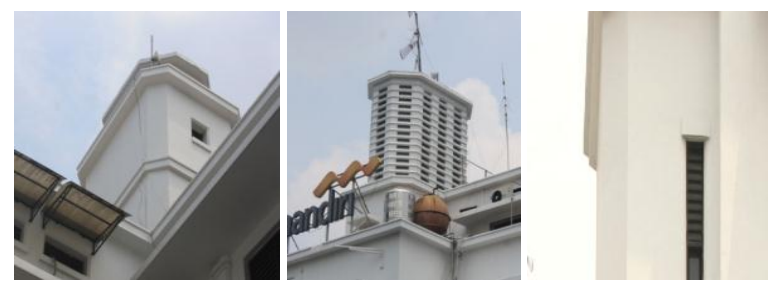

Fig. 17. The expressive towers and corner of the building were curved

From the result of the analysis, the conclusion is Mandiri KC Medan City Hall Bank is a Dutch colonial building that was influenced by Nieuwe Bouwen Expressionism.

\section{CONCLUSION}

Nieuwe Bouwen architecture is one of the modern architecture style in Netherland which means New Building. This architecture is consist of three types, namely Nieuwe Bouwen Expressionism, Nieuwe Bouwen Functionalism, and Nieuwe Bouwen Local. The results of analysis based on the 6 aspects of research shows that the development of Nieuwe Bouwen Architecture in Medan City is influenced by the Architecture Nieuwe Bouwen Expressionism. The three research objects indicate that:

- Expressionism forms in PD Pasar Office in Medan were in the shape of the building that was curving, unique, and there was expressive ventilation. Besides that, there were the ornament and decorative element on the facade of the building.
- Expressionism form in Paradiso Swimming Pool was in the shape of the building that was curving. Besides that, there were the geometric ornaments, and the decorative elements don't function as structure, and there were expressive balcony and tower.

- Expressionism forms in Mandiri KC Medan City Hall Bank were on the geometric ornaments, decorative elements don't function as a structure, and there were expressive balcony and tower.

Expressionism forms was found in all of the objects of research that analyzed with 6 (six) aspects showed the influence of Nieuwe Bouwen Architecture Expressionism (Table 1).

The author expects that the government and the society participate in caring for and preserving the Dutch colonial buildings in the City of Medan, such as Paradiso swimming pool, Mandiri KC Medan City Hall Bank, especially PD Pasar Office Medan. The objects of the study, PD Pasar Office building whose condition is the most unmaintained. Many societies who don't know that the buildings were historic buildings that must be preserved.

\section{ACKNOWLEDGEMENT}

The author would like to thank the Department of Architecture, Faculty of Engineering, University of Sumatra Utara for the opportunity to do this research. My gratitude is to those who also have helped in the research activities from the beginning to the end.

\section{REFERENCES}

Bergeijk, Door Hervan van \& Dudok, W. M. (2001). W.M Dudok. Rotterdam: 010 Publishers.

Bogdanovic, J. et al. (2014). On The Very Edge "Modernism and Modernity in the Arts and Architecture of Interwar Serbia (1918-1941)". Belgia: Leuven University Press.

Dietz, et al. (1995). Het Nieuwe Bouwen in Nederland and Slowakije 1918-1940. Amsterdam: Van Dijk, Van Soomeren en Partners (DSP).

Handinoto (1996). Perkembangan Kota dan Arsitektur Kolonial Belanda di Surabaya (18701940). Yogyakarta: ANDI.

Handinoto (2010). Arsitektur dan Kota-Kota di Jawa pada Masa Kolonial. Yogyakarta: Graha Ilmu.

Harmans, G. M. L. (2011). DK Eyewitness Travel Guide: The Netherlands: The Netherlands. New York: DK Publishing.

Ibelings, H. (1995). 20 th Century Architecture in the Netherlands. Rotterdam: NAi Publishers.

Krier, R. (2001). Komposisi Arsitektur. Jakarta: Erlangga. 
Tabel 1. Aspects of Architecture Nieuwe Bouwen contained in Research Objects

\begin{tabular}{|c|c|c|c|c|c|c|}
\hline & The dynamic form & $\begin{array}{l}\text { Expressive } \\
\text { ornaments }\end{array}$ & $\begin{array}{l}\text { The building has a } \\
\text { tower }\end{array}$ & $\begin{array}{c}\text { Nonstructural } \\
\text { elements }\end{array}$ & $\begin{array}{c}\text { Glass, steel, and } \\
\text { concerete materials }\end{array}$ & $\begin{array}{c}\text { Elements of air, light, } \\
\text { and space }\end{array}$ \\
\hline \multirow[t]{2}{*}{$\begin{array}{l}\text { PD Pasar } \\
\text { Office Medan }\end{array}$} & 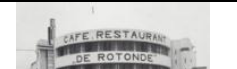 & & & & & \\
\hline & $\checkmark$ & $\checkmark$ & $\checkmark$ & $\checkmark$ & $\checkmark$ & $\checkmark$ \\
\hline \multirow[t]{2}{*}{$\begin{array}{l}\text { Paradiso } \\
\text { Swimming } \\
\text { Poll }\end{array}$} & & & & & & \\
\hline & $\checkmark$ & $\checkmark$ & $\checkmark$ & $\checkmark$ & $\checkmark$ & $\checkmark$ \\
\hline \multirow[t]{2}{*}{$\begin{array}{l}\text { Mandiri KC } \\
\text { Medan City } \\
\text { Hall Bank }\end{array}$} & mompr & & & & $\frac{5 \times 11}{4 x+1}$ & \\
\hline & $\checkmark$ & $\checkmark$ & $\checkmark$ & $\checkmark$ & $\checkmark$ & \\
\hline
\end{tabular}

Kolman, C. et.al. (1997). Monumenten in Nederland. Noord-Brabant. Zwolle: Zeist/Waanders Publishers.

Muller, S. D. (2011). Dutch Art: An Encyclopedia. New York: Routledge.

Rebel, B. (1983). Het Nieuwe Bouwen: Amsterdam 1920-1960. Delft: Delft University.

Samuel, I. et.al. (2004). Urban Forms: The Death and Life of the Urban Block. Oxford: Architectural Press.

Segaar-Höweler \& Dorothee C. (1998). J.M. Groenewegen (1888-1980). Een Hagenaar als Indonesisch Architect. Rotterdam: TU Delft.
Sinuligga, S. (2012). Metode Penelitian. Medan: USU Press.

Sumalyo, Y. (1997). Arsitektur Modern (Akhir Abad XIX dan XX). Yogyakarta: Gadjah Mada University Press.

Wahid, J. \& Alamsyah, B. (2013). Teori Arsitektur: Suatu Kajian Perbedaan Pemahaman Teori Barat dan Timur. Yogyakarta: Graha Ilmu.

Wertheimer, L. (2004). Architectural History. Chicago: Kaplan AEC Architecture.

Amsterdam School (http://www.amsterdam.info/ architecture/amsterdam-school/) was accessed on May $6^{\text {th }}, 2016$. 